\title{
PENGEMBANGAN MODUL IPA TERINTEGRASI DENGAN AYAT AL QUR'AN DAN HADIS
}

\author{
Nafi'atus Sholihah', Ika Kartika ${ }^{2}$ \\ 1,2Universitas Islam Negeri Sunan Kalijaga Yogyakarta \\ 1,2Jl. Laksda Adisucipto, Caturtunggal, Kecamatan Depok, Kabupaten Sleman, Yogyakarta \\ Email: nafiatussholihah55@gmail.com¹, ika_thea@yahoo.co.id ${ }^{2}$
}

\begin{abstract}
Abstrak:
Penelitian ini bertujuan untuk (1) menghasilkan modul IPA terintegrasi dengan ayat Alquran dan hadis (2) mengetahui kualitas modul IPA terintegrasi dengan ayat Alquran dan hadis yang telah dikembangkan (3) mengetahui respons peserta didik dan keterlaksanaan modul IPA terintegrasi dengan ayat Alquran dan hadis yang dikembangkan. Penelitian ini merupakan penelitian research and development (R\&D). Prosedur penelitian pengembangan ini berdasarkan model 4-D. Penelitian ini menghasilkan modul IPA terintegrasi dengan ayat Al Qur'an dan hadis dikembangkan dengan mengacu pada model informatif. Kualitas modul IPA berdasarkan penilaian ahli materi, ahli grafika, ahli integrasi-interkoneksi, dan guru IPA memperoleh klasifikasi Sangat Baik (SB) dengan rerata skor berturutturut 3,$45 ; 3,35 ; 3,54 ;$ dan 3,40 . Respons peserta didik terhadap modul pada uji terbatas dan uji luas memperoleh klasifikasi Setuju (S) dengan rerata skor berturutturut 0,88 dan 0,87 .
\end{abstract}

\begin{abstract}
:
This study aims to (1) produce IPA module integrated with Qur'anic verses and hadiths (2) to know the quality of IPA module integrated with Qur'anic verses and hadiths that has been developed (3) to know the response of learners and the implementation of IPA module integrated with the Qur'anic verses and hadith that has been developed. This research is a research and development (R\&D) research. The procedure of the research was based on 4-D model. This study developed an IPA module integrated with Qur'anic verses and hadith using the informative model. The quality of IPA module based on the assessment of material experts, graphicians, integration-interconnection experts, and IPA teachers obtained excellent classification with a consecutive mean score of 3.45; 3.35; 3.54; and 3.40. The learner's response to the module on the limited test and the broad test obtained the agreed classification with a mean score of 0.88 and 0.87 .
\end{abstract}

Kata kunci:

Integrasi Ayat Al Qur'an dan Hadis, Modul IPA, Sumber Belajar

MADRASAH Tsanawiyah merupakan salah satu lembaga pendidikan formal yang sederajat dengan Sekolah Menengah Pertama (SMP) yang berbasis keislaman (Daulay: 2004). Sebagai lembaga yang berbasis keislaman, madrasah memiliki peranan yang 
penting dalam pembentukan kepribadian peserta didik, karena melalui pendidikan madrasah para orang tua berharap anak-anaknya memiliki dua kemampuan sekaligus, tidak hanya pengetahuan umum yang berhubungan dengan ilmu pengetahuan dan teknologi (IPTEK) tetapi juga memiliki kepribadian dan komitmen yang tinggi terhadap agamany, yakni iman dan taqwa (IMTAQ) (Riesmawati, 2014).

Demi tercapainya kemampuan dalam bidang IPTEK dan keagamaan maka, berbagai sarana dan prasarana dipersiapkan. Persiapan tersebut juga disesuaikan dengan perkembangan IPTEK dan karakteristik peserta didik di madrasah, sehingga sarana dan prasarana yang disiapkan selaras dengan kebutuhan. Daryanto (2013: 4) mengungkapkan bahwa perkembangan IPTEK yang begitu pesat berdampak pada diperkayanya sumber belajar dan media pembelajaran. Selain itu perkembangan IPTEK yang berlangsung semakin cepat, tidak memungkinkan lagi bagi pendidik khususnya guru mengajarkan semua konsep dan fakta kepada peserta didik. Oleh karena itu, peserta didik harus dibiasakan untuk memperoleh informasi secara mandiri, sehingga peserta didik harus memiliki sikap kemandirian dalam belajar. Setelah mengetahui bagaimana dampak dari perkembangan IPTEK yang menekankan pada kemandirian belajar, maka dilakukan identifikasi karakteristik peserta didik khususnya karakteristik belajar peserta didik.

Berdasarkan penyebaran angket di Madrasah Tsanawiyah Negeri 1 Yogyakarta diperoleh data tentang karakteristik belajar peserta didik di luar sekolah sebagai berikut: 68,75\% peserta didik lebih senang belajar mandiri dengan penuh konsentrasi, $27,08 \%$ belajar secara kelompok, dan 4,16\% belajar dengan guru privat. Gaya belajar mandiri yang digemari peserta didik belum terfasilitasi dengan baik, karena 77,08\% peserta didik menyatakan belum memiliki sumber belajar khususnya berbasis cetakan yang mendukung belajar mandiri mereka.

Hakikat IPA merupakan gejala-gejala alam pada dimensi pengetahuan (keilmuan) yang dapat dikaitkan pada dimensi nilai ukhrawi, yakni dengan memperhatikan keteraturan di alam semesta akan semakin meningkatkan keyakinan akan adanya sebuah kekuatan yang Maha dahsyat yang tidak dapat dibantah lagi, yaitu Allah Swt (Chandra dan Yudyanto, 2013). Dimensi ini menggambarkan hakikat IPA adalah menautkan antara aspek logika-materil dengan aspek spiritual, yang sementara ini dianggap cakrawala kosong, karena suatu anggapan antara IPA dan agama merupakan dua sisi yang berbeda dan tidak mungkin dipersatukan satu sama lain dalam satu bidang kajian. Pada kenyataannya terdapat benang merah keterkaitan di antara keduanya (Arlitasari dkk, 2013).

Berdasarkan pernyataan tersebut, dibutuhkan sumber belajar yang mendukung belajar mandiri peserta didik. Salah satu sumber belajar mandiri yang sesuai dan berbasis cetakan adalah modul. Prastowo (2014: 208) mengungkapkan bahwa modul adalah sebuah buku yang ditulis dengan tujuan agar peserta didik belajar mandiri tanpa atau dengan bimbingan seorang guru. Pemilihan modul sebagai sumber belajar mandiri bagi peserta didik diperkuat dengan hasil penelitian Rosa (2015) yang menunjukkan bahwa modul sangat membantu peserta didik belajar mandiri, 
diperlukan sebagai panduan belajar, dan dinilai efektif untuk meningkatkan kemampuan belajar peserta didik. Penyusunan modul sebagai sumber belajar mandiri tidak hanya pada aspek kognitif tetapi juga pada aspek keagamaan sesuai dengan tujuan pendidikan madrasah yang menghendaki peserta didik mempunyai kemampuan dalam bidang pengetahuan dan bidang keagamaan, sehingga modul yang disusun diintegrasikan dengan ayat Al Qur'an dan hadis. Pengintegrasian juga berupaya untuk memenuhi tujuan Sistem Pendidikan Nasional yaitu pendidikan nasional berfungsi mengembangkan kemampuan dan membentuk watak serta peradaban bangsa yang bermartabat dalam rangka mencerdaskan kehidupan bangsa, bertujuan untuk berkembangnya potensi peserta didik agar menjadi manusia yang beriman dan bertakwa kepada Tuhan Yang Maha Esa, berakhlak mulia, sehat berilmu, cakap, kreatif, mandiri, dan menjadi warga negara yang demokratis serta bertanggung jawab.

Berdasarkan pernyataan sebelumnya, maka peneliti mengembangkan modul IPA terintegrasi dengan ayat Al Qur'an dan hadis yang dapat memfasilitasi belajar mandiri peserta didik. Selain memfasilitasi peserta didik dalam belajar mandiri, pengembangan modul bertujuan memperluas wawasan peserta didik bukan hanya pada materi IPA tetapi juga pada penanaman nilai-nilai moral dan keagamaan, pada akhirnya peserta didik memiliki kebermaknaan ilmu dikarenakan kesyukurannya terhadap ciptaan Tuhan Yang Maha Esa dan kesadaran mereka terhadap ayat-ayat yang ada di alam semesta.

\section{METODE PENELITIAN}

Penelitian ini merupakan penelitian pengembangan ( $R$ \& D) yang bertujuan untuk menghasilkan produk baru melalui proses pengembangan (Mulyatiningsih, 2011: 161). R \& D adalah suatu proses yang digunakan untuk mengembangkan dan memvalidasi produk pendidikan (Borg and Gall, 1983: 772). Prosedur dalam penelitian ini mengadopsi pada prosedur penelitian pengembangan model 4D yang dikembangkan oleh Thiagarajan. Model 4-D terdiri dari 4 langkah yaitu define, design, develop, dan dessiminate. Dalam penelitian pengembangan ini, langkah-langkah 4-D disesuaikan dengan kebutuhan pada penelitian, yaitu yang dibatasi sampai tahap develop dan pada tahap development testing. Adapun langkah-langkah penelitian dapat dilihat pada gambar 1 . 


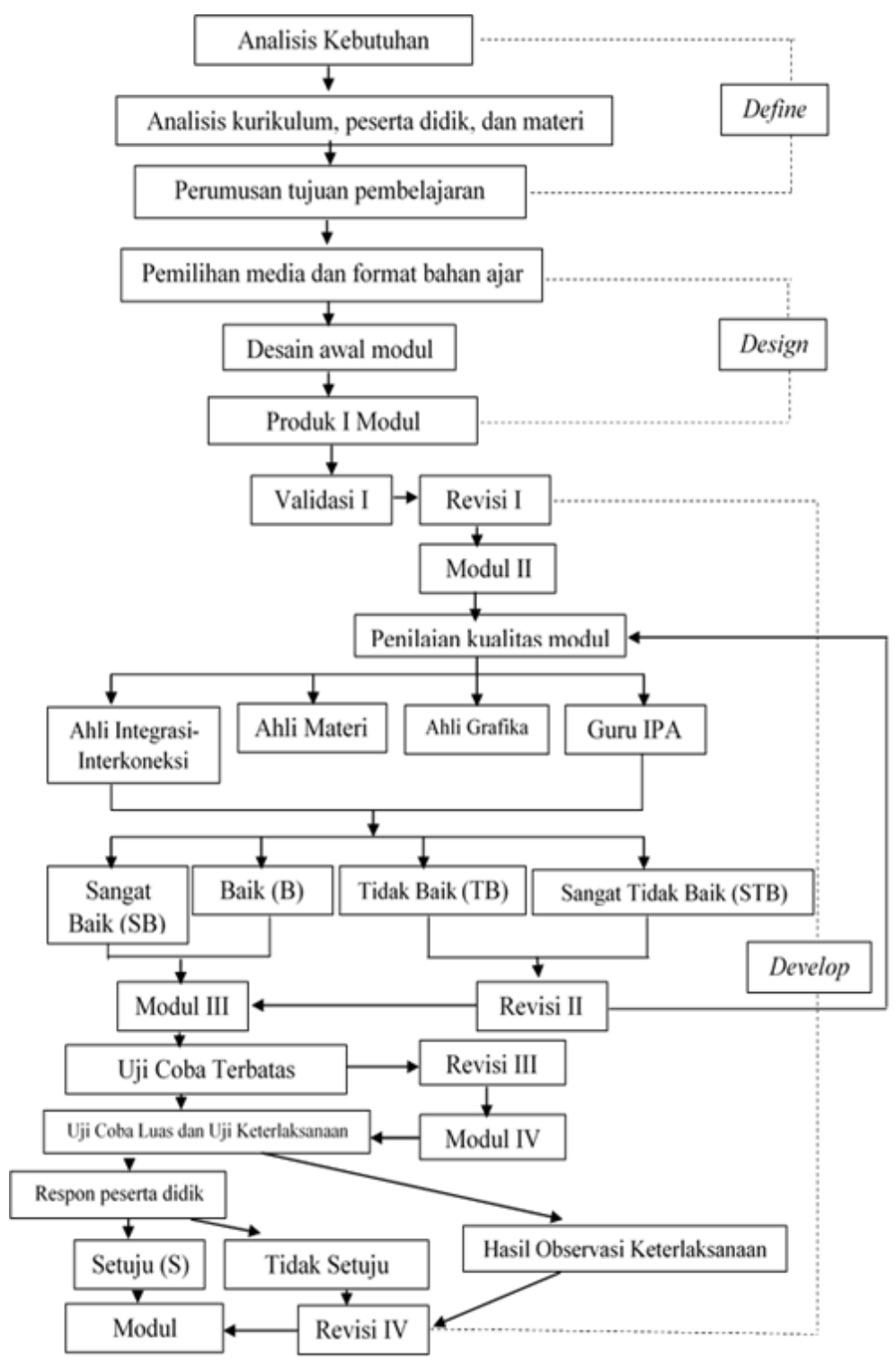

Gambar 1. Alur Penelitian Pengembangan

Desain uji coba modul menggunakan desain deskriptif seperti gambar 1. Uji coba dilakukan dua kali, yaitu uji coba terbatas dan uji coba luas. Subjek uji coba dalam penelitian ini adalah 8 penilai ( 3 ahli materi, 2 ahli integrasi-interkoneksi, 2 ahli media, dan 1 guru IPA). Responden uji coba terbatas ada 7 peserta didik kelas VIII dan responden uji coba luas adalah 29 peserta didik kelas VIII (Mulyatiningsih, 2011: 164).

Data hasil uji coba berupa data kualitatif dan kuantitatif, data kualitatif merupakan data kritik dan saran dari validator, penilaian penilai, dan respons peserta didik. Data kuantitatif berupa skor penilaian setiap poin kriteria penilaian dari data kualitatif pada lembar penilaian yang diisi oleh ahli materi, ahli media, ahli integrasiinterkoneksi, dan guru IPA kelas VIII diubah menjadi skala skor dengan skala likert yaitu Sangat Baik (SB): 4, Baik (B): 3, Tidak Baik (TB): 2, dan Sangat Tidak Baik (STB): 
1. Untuk respons peserta didik kemudian diubah ke skala Guttman dengan Setuju (S): 1 dan Tidak Setuju (TS): 0 untuk pernyataan positif dan S: 0 serta TS: 1 untuk pernyataan negatif (Widoyoko, 2012: 18-22).

Menurut Widoyoko (2013: 33) teknik pengumpulan data adalah strategi atau cara yang digunakan oleh peneliti untuk mengumpulkan data yang diperlukan dalam penelitian. Instrumen penelitian yang digunakan terdiri dari empat instrument. Pertama, lembar kritik dan saran validator. Lembar kritik dan saran digunakan pada tahap validasi, baik validasi instrumen maupun validasi produk, instrumen penilaian maupun instrumen respons peserta didik. Kedua, lembar penilaian kuliatas modul IPA. Instrumen disini digunakan untuk mengetahui kualitas modul yang dikembangkan. Adapun penilaian modul dilakukan oleh ahli media, ahli materi, ahli integrasi-interkoneksi, dan guru IPA kelas VIII. Ketiga, lembar respons peserta didik. Lembar respons peserta didik berupa lembar angket yang disajikan dalam bentuk checklist setuju atau tidak setuju atas pertanyaan yang ada. Keempat, lembar observasi keterlaksanaan peserta didik. Lembar keterlaksanaan ini digunakan dalam tahap uji pengembangan yaitu uji luas. Hasil observasi keterlaksanaan ini bertujuan untuk mengetahui keterlaksanaan modul IPA. Hasil pengamatan berupa deskripsi.

Teknik analisis data yang digunakan dalam penelitian ini, sebagai berikut: pertama, analisis penilaian kualitas produk. Penilaian kualitas modul dilakukan oleh ahli materi, ahli media, ahli integrasi-interkoneksi, dan guru IPA kelas VIII. Penilaian untuk setiap pernyataan dengan skala likert 4: Sangat Baik (SB), 3: Baik (B), 2: Tidak Baik (TB), dan 1: Sangat Tidak Baik (STB). Pengubahan hasil penilaian para ahli dari data kualitatif ke bentuk data kuantitatif (skor) dengan ketentuan seperti yang dinyatakan oleh Widoyoko (2013: 105). Kedua, analisis data respons peserta didik. Jawaban peserta didik dikategorikan ke dalam pernyataan S (Setuju) bernilai 1 dan TS (Tidak Setuju) bernilai 0. Skala pengukuran ini akan mendapatkan jawaban yang tegas (jelas) dan konsisten terhadap suatu permasalahan yang dinyatakan, kemudian dihitung skor rata-rata dengan persamaan berikut:

$$
\begin{aligned}
\text { jarak interval }(\mathrm{i}) & =\frac{\text { skor tertinggi-skor terendah }}{\text { jumlah kelas interval }} \\
& =\frac{1-0}{2} \\
& =0,50
\end{aligned}
$$

\section{HASIL PENELITIAN DAN PEMBAHASAN \\ Penilaian Kualitas Modul IPA}

Penilaian dilakukan untuk mengetahui kualitas modul IPA yang telah dikembangkan dari aspek isi dan penyajian yang berbeda dengan penelitian yang dilakukan oleh Latifah dan Ratnasari dalam Jurnal Penelitian Pembelajaran Fisika yang menambahkan penilaian kebahasaan yang menggunakan skala interpretasi (\%). Pada penelitian ini menggunakan skala Guttman dengan skala 4. Adapun penilai terdiri dari 
3 ahli materi, 2 ahli grafika, 2 ahli integrasi-interkoneksi, dan 1 guru IPA. Berikut penilaian ahli materi:

Tabel 1. Hasil Penilaian Ahli Materi

\begin{tabular}{cccc}
\hline No & Aspek & $\begin{array}{c}\text { Rerata } \\
\text { Skor }\end{array}$ & Klasifikasi \\
\hline 1 & Aspek kelayakan & 3,51 & Sangat Baik (SB) \\
2 & $\begin{array}{c}\text { materi/isi } \\
\text { Aspek penyajian }\end{array}$ & 3,33 & Sangat Baik (SB) \\
\hline & Keseluruhan & 3,42 & Sangat Baik (SB) \\
\hline
\end{tabular}

Kebenaran konsep dan definisi diperoleh dengan menggunakan berbagai referensi agar materi yang disajikan akurat, tidak hanya dari buku peserta didik tetapi dari buku-buku lain yang memuat materi. Prastowo (2013: 276) menyatakan bahwa materi dapat diambil dari berbagai sumber seperti buku, majalah, internet, jurnal penelitian dan sebagainya.

Tabel 2. Hasil Penilaian Ahli Grafika

\begin{tabular}{cccc}
\hline No & Aspek & $\begin{array}{c}\text { Rerata } \\
\text { Skor }\end{array}$ & Klasifikasi \\
\hline $\mathbf{1}$ & Aspek bahasa dan gambar & 3,21 & Baik (B) \\
$\mathbf{2}$ & Aspek kegrafikaan & 3,50 & Sangat Baik (SB) \\
\hline & Keseluruhan & 3,35 & Sangat Baik (SB) \\
\hline
\end{tabular}

Penilaian aspek bahasa dan gambar diperoleh rerata skor 3,21. Pada aspek ini yang dinilai antara lain adalah kejelasan gambar, keakuratan gambar, tata layout gambar, keterangan kejelasan pada gambar, kesesuaian ejaan dengan EYD, dan ketepatan dalam penggunaan tanda baca. Sedangkan pada aspek kegrafikaan diperoleh rerata skor 3, 50 bagian yang dinilai adalah penampilan cover, penampilan setiap lembar dalam modul, ketepatan variasi huruf yang digunakan, dan kesesuaian ukuran huruf.

Tabel 3. Hasil Penilaian Ahli Integrasi-interkoneksi

\begin{tabular}{cccc}
\hline No & Aspek & $\begin{array}{c}\text { Rerata } \\
\text { Skor }\end{array}$ & Klasifikasi \\
\hline $\mathbf{1}$ & $\begin{array}{c}\text { Aspek Integrasi- } \\
\text { interkoneksi }\end{array}$ & 3,33 & Sangat Baik (SB) \\
$\mathbf{2}$ & $\begin{array}{c}\text { Aspek model integrasi- } \\
\text { interkoneksi }\end{array}$ & 3,75 & Sangat Baik (SB) \\
\hline & Keseluruhan & 3,54 & Sangat Baik (SB) \\
\hline
\end{tabular}


Pernyataan yang digunakan dalam penilaian didasarkan pada konsep integrasiinterkoneksi yaitu upaya memadukan antara ilmu-ilmu agama (Islam) dan ilmu-ilmu umum (sains-teknologi dan sosial humaniora) (Mu'tashim, 2006: 26). Adapun model yang digunakan dalam pengembangan modul IPA ini adalah model informatif. Model informatif menurut $\mathrm{Mu}$ 'tashim (2006: 32) suatu disiplin ilmu yang memberikan informasi kepada disiplin ilmu lain sehingga dapat memperluas wawasan dan ilmu pengetahuan. Perolehan rerata skor pada aspek ini sebesar 3,75 yang memenuhi klasifikasi sangat baik (SB).

Pada penilaian ahli grafika dan ahli integrasi-interkoneksi pada penelitian ini berada pada kategori yang berbeda untuk memudahkan dalam analisa data yang didapatkan dari hasil penilaian. Hal tersebuat berbeda dengan penelitian Lathifah dan Ratnasari yang menggabungkan dua penilaian ke dalam satu kategori penilaian.

Tabel 4. Hasil Penilaian Guru IPA

\begin{tabular}{cccc}
\hline No & Aspek & $\begin{array}{c}\text { Rerata } \\
\text { Skor }\end{array}$ & Klasifikasi \\
\hline 1 & Aspek kelayakan materi/isi & 3,30 & Sangat Baik (SB) \\
2 & Aspek penyajian & 3,50 & Sangat Baik (SB) \\
3 & Aspek bahasa dan gambar & 3,57 & Sangat Baik (SB) \\
4 & Aspek kegrafikaan & 3,33 & Sangat Baik (SB) \\
& Keseluruhan & 3,40 & Sangat Baik (SB) \\
\hline
\end{tabular}

Penilaian modul IPA terintegrasi dengan ayat Al Qur'an dan hadis tidak hanya dilakukan oleh ahli tetapi juga oleh guru IPA. Hal ini sangat diperlukan karena guru mempunyai peran yang sangat penting dalam proses pembelajaran di sekolah seperti mempersiapkan bahan ajar yang tepat khususnya bahan ajar yang mendukung kurikulum dan sistem madrasah.

Penilaian yang dilakukan oleh guru IPA mencakup 4 aspek yaitu aspek bahasa dan gambar, aspek kelayakan materi/isi, aspek penyajian, serta aspek kegrafikaan. Dari keempat aspek tersebut secara berturut-turut rerata skornya adalah pada aspek bahasa dan gambar dengan skor rerata 3,57. Penilaian pada aspek ini meliputi kejelasan gambar yang digunakan, keterangan gambar yang jelas, ketepatan tata letak layout, keakuratan gambar, kesesuaian ejaan dengan EYD, dan penggunaan tanda baca yang tepat.

Kebenaran materi dilakukan dengan mengombinasikan beberapa referensi sehingga materi yang disajikan akurat. Prastowo (2013: 276) menyatakan bahwa materi dapat di ambil dari berbagai sumber seperti buku, majalah, internet, jurnal hasil penelitian dan sebagainya. Variasi bentuk soal pada modul adalah soal pilihan ganda dan soal uraian dengan jumlah masing-masing soal adalah lima soal. Pembuatan soal disesuaikan tingkat kesukaran dan disesuaikan dengan ranah Taksonomi Bloom yang mencakup C1-C4 untuk tingkat SMP dan sederajat. 


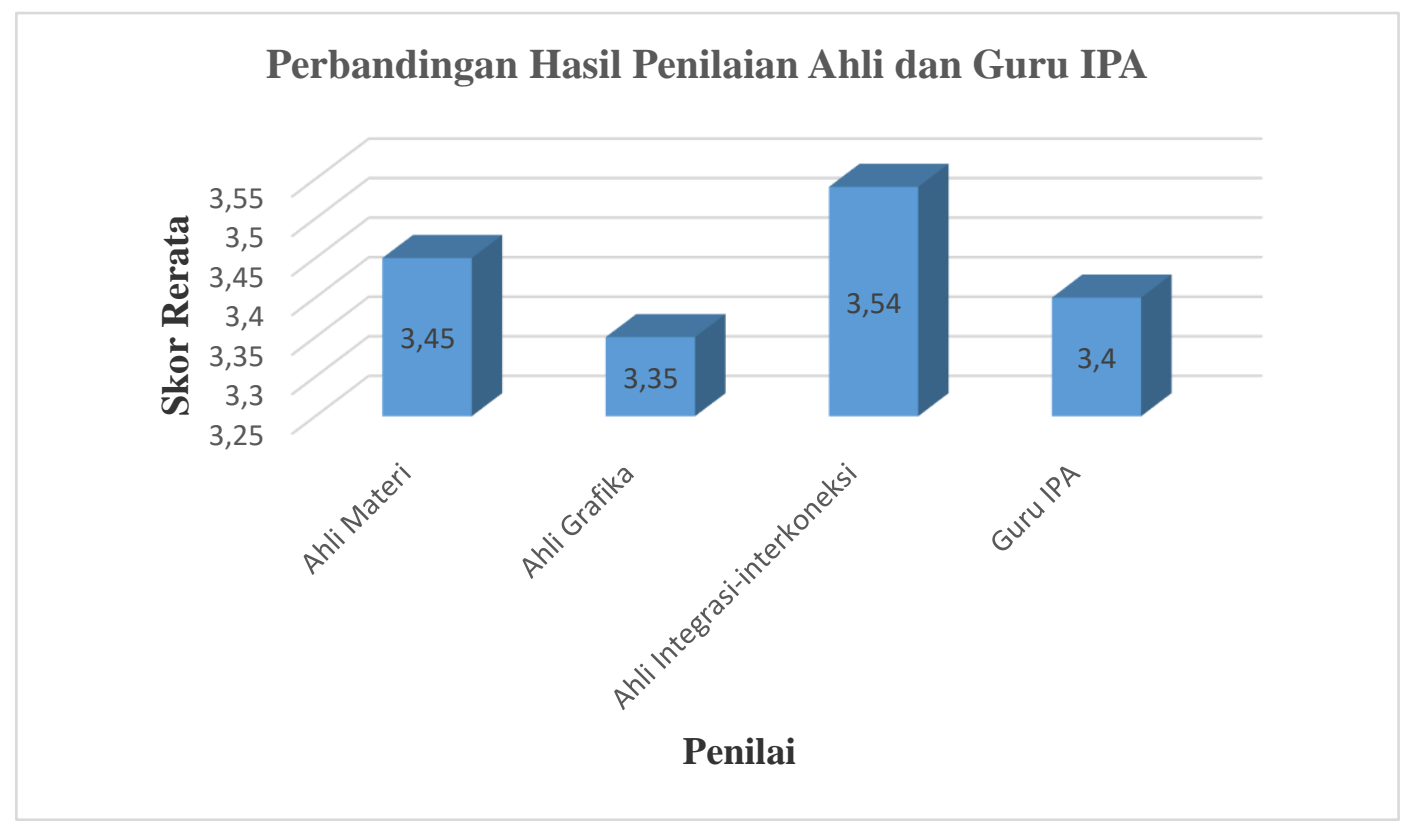

Diagram 1. Perbandingan Hasil Penilaian

Diagram 1 menunjukkan perbandingan hasil penilaian antara ahli materi, ahli grafika, ahli integrasi-interkoneksi, dan guru IPA yang menyatakan bahwa penilaian berturut-turut dari penilaian tertinggi adalah penilaian oleh ahli integrasi-interkoneksi, ahli materi, guru IPA dan ahli grafika. Keseluruhan penilaian memenuhi klasifikasi sangat baik (SB) yang ditunjukkan dengan besar rerata skor lebih besar dari 3,25.

\section{Respons Peserta Didik}

Respons peserta didik diperoleh dari pengisian lembar angket oleh peserta didik pada saat dilaksanakan uji terbatas dan uji luas. Respons peserta didik ini dinyatakan dalam dua klasifikasi yaitu setuju (S) dan tidak setuju (TS). Responden untuk uji terbatas dan uji luas adalah peserta didik kelas VIII MTs N 1 Yogyakarta, dengan uji terbatas sebanyak tujuh responden dan uji luas sebanyak 29 responden. Lembar angket respons yang digunakan mencakup tiga aspek yaitu aspek isi, penyajian, dan bahasa. Ketiga aspek ini kemudian dijabarkan menjadi 16 pernyataan. Pernyataan pada lembar angket respons peserta didik terdiri dari pernyataan positif dan negatif, hal ini dilakukan untuk menguji kekonsistenan peserta didik dalam menjawab.

\section{Uji Terbatas}

Uji terbatas dilakukan pada tanggal 15 Juni 2017 di MTs N 1 Yogyakarta. Aspek isi diperoleh rerata skor 0,94 , aspek penyajian diperoleh rerata skor 0,92 , dan aspek bahasa diperoleh rerata skor 0,92 . Secara keseluruhan respons peserta didik pada uji terbatas memperoleh respons setuju (S) dengan skor rerata secara keseluruhan adalah 0,93 . Uji terbatas dilakukan hanya untuk mengetahui bagaimana respons peserta didik terhadap modul IPA. 


\section{Uji Luas}

Uji luas dilaksanakan pada tanggal 17 Juni 2017 di MTs N 1 Yogyakarta. Pada uji luas diperoleh rerata skor pada masing-masing aspek sebagai berikut aspek isi memperoleh rerata skor 0,86, aspek bahasa memperoleh rerata skor 0,96, dan pada aspek penyajian memperoleh rerata skor 0,84 . Keseluruhan aspek menunjukkan bahwa respons peserta didik setuju (S). Rerata skor keseluruhan aspek adalah 0,87.

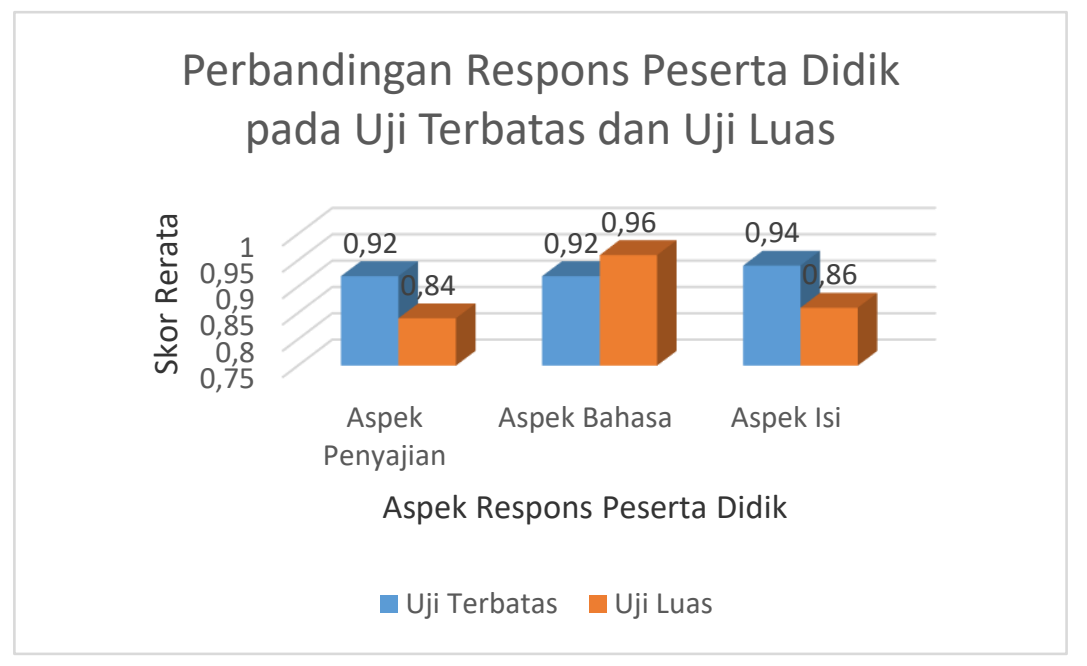

Diagram 2. Perbandingan Respons Peserta Didik

Berdasarkan diagram 2, rerata skor respons peserta didik mempunyai selisih yang kecil antara rerata skor respons peserta didik pada uji terbatas dan uji luas. Semua aspek pada uji terbatas dan uji luas menunjukkan bahwa respons peserta didik memenuhi klasifikasi setuju (S). Hal ini menggambarkan bahwa modul IPA terintegrasi dengan ayat Alquran dan hadis yang dikembangkan dapat diterima dan digunakan oleh peserta didik.

Keterlaksanaan modul IPA pada uji luas menyatakan bahwa peserta didik tertarik dengan modul IPA yang dikembangkan karena sudah lengkap dan disertai gambar-gambar yang menjadi daya tarik tersendiri serta mereka bisa dengan mudah memilih dan merencanakan kegiatan belajar sendiri. Modul sudah lengkap sehingga tidak perlu adanya media lain saat peserta didik mempelajarinya. Ada bagian dari modul terkait istilah sulit yang belum tertulis di glosarium, sehingga saat peserta didik membaca materi secara mandiri mereka bertanya-tanya. Dalam pengerjaan soal evaluasi, empat peserta didik mengalami kesulitan khususnya menjawab soal uji kompetensi 3 nomor 2, peserta didik mengatakan bahwa pertanyaan yang dibuat tidak terdapat pada materi. Untuk soal nomor 4 dan 5 pada soal uji kompetensi 4 tidak terlaksana dalam pengerjaannya dikarenakan keterbatasan waktu saat menyelesaikan soal. Beberapa kendala dan kesulitan yang dialami oleh peserta didik dijadikan bahan perbaikan untuk menyempurnakan modul IPA menjadi produk akhir. Observer dari 
guru IPA menyarankan untuk meninjau ulang tingkat kesukaran pada soal uji kompetensi dan tes akhir.

\section{SIMPULAN}

Berdasarkan hasil penelitian dan pembahasan, diperoleh kesimpulan sebagai berikut. Pertama, penelitian ini menghasilkan modul IPA terintegrasi dengan ayat Al Qur'an dan hadis yang dikembangkan berdasarkan analisis kebutuhan yang meliputi analisis kurikulum, analisis karakteristik peserta didik, dan analisis materi di MTsN 1 Yogyakarta. Kedua, kualitas modul IPA terintegrasi dengan ayat Alquran dan hadis dinilai sangat baik (SB) oleh ahli materi, ahli grafika, ahli integrasi-interkoneksi, dan guru IPA dengan perolehan rerata skor secara berturut-turut sebagai berikut 3,$45 ; 3,35$; 3,54; dan 3,40. Ketiga, respons peserta didik terhadap modul IPA terintegrasi dengan ayat Alquran dan hadis pada uji terbatas dan uji luas memperoleh kriteria yang sama yaitu setuju (S) dengan perolehan rerata skor untuk uji terbatas 0,88 dan uji luas 0,87. Adapun keterlaksanaan modul IPA pada uji luas menunjukkan bahwa pada pengerjaan evaluasi empat peserta didik mengalami kesulitan khususnya menjawab soal uji kompetensi 3 nomor 2, peserta didik mengatakan bahwa pertanyaan yang dibuat tidak terdapat pada materi. untuk soal uji kompetensi nomor empat dan lima tidak terlaksana pengerjaannya. Untuk aspek lain sudah terlaksana dengan baik.

\section{DAFTAR PUSTAKA}

Arlitasari O, Pujayanto, \& Budiharti R. (2013). Pengembangan Bahan Ajar IPA Terpadu Berbasis Salingtemas dengan Tema Biomassa Sumber Energi Alternatif Terbarukan. Jurnal Fakultas Keguruan dan Ilmu Pendidikan Universitas Sebelas Maret dalam Jurnal Pendidikan Fisika.

Borg \& Gall. (1983). Educational Research an Introduction Fourth Edition. New York: Longman.

Chandra, F. L., \& Yudyanto S. (2013). Pengembangan Lembar Kerja Siswa (LKS) Fisika Materi Tekanan Mencakup Ranah Kognitif, Afektif, dan Psikomotor sesuai Kurikulum 2013 untuk Siswa SMP/MTs. Jurnal Program Studi Fisika FMIPA Universitas Negeri Malang.

Daryanto. (2013). Standar Kompetensi dan Penilaian Kinerja Guru Profesional. Yogyakarta: Gava Media

Depdiknas. (2003). Pedoman Penulisan Modul. Jakarta: Direktorak Pendidikan Menengah Kejuruan, Direktorat Jenderal Pendidikan Dasar dan Menengah.

Daulay, H. P. (2004). Pendidikan Islam: Dalam Sistem Pendidikan Nasional di Indonesia. Jakarta: Kencana.

Riesmawati. (2014). Manajemen Pengembangan Madrasah (MTs) Negeri di Kotaagung. Skripsi. Fakultas Ilmu Pendidikan Universitas Lampung.

Leksana, D. M., Mungin, E. W., \& Imam, T. (2013). Pengembangan Modul Bimbingan Karir Berbasis Multimedia Interaktif untuk Meningkatkan Kematangan Karir Siswa. Jurnal Bimbingan Konseling, (1). 
Mulyatiningsih, E. (2013). Metode Penelitian Terapan Bidang Pendidikan. Bandung: Alfabeta.

Mu'tashim, R., dkk. (2006). Kerangka Dasar Keilmuan dan Pengembangan Kurikulum. Yogyakarta: Pokja Akademika UIN Sunan Kalijaga.

Prastowo, A. (2014). Pengembangan Bahan Ajar Tematik. Jakarta: Prenada Media Group.

Rosa, F. O. (2015). Pengembangan Modul Pembelajaran IPA SMP Pada Materi Tekanan Berbasis Keterampilan Proses Sains. Jurnal Pendidikan Fisika, 3 (1).

UU RI Nomer 20. (2003). Sistem Pendidikan Nasional. www.hukumonline.com. Diakses tanggal 18 Februari 2017.

Widoyoko, E. P. (2012). Teknik Penyusunan Instrumen Penelitian. Yogyakarta: Pustaka Pelajar. 